\title{
Assessment of Antiulcer Activity of Ethanol Extract of Ficus religiosa Fruit in Pylorus Ligated and Aspirin induced Ulceration in Experimental Animals
}

\section{Harikesh Yadav ${ }^{1}$, Virendra Kumar Maurya ${ }^{2}$, Bhavana Yadav로 Pankaj Kumar ${ }^{3}$, Ashok Kumar Yadav ${ }^{3}$, Asha Roshan ${ }^{1}$}

${ }^{1}$ R. K. Pharmacy College, Sathiaon, Azamgarh-276403 (UP), India

${ }^{2}$ Smt Fulehra Smarak College of Pharmacy, Ballia-221712 (UP), India

${ }^{3}$ VMY College of Pharmacy, Madhuban, Mau (UP), India

Article Information

Received 2 February 2020

Received in revised form 6 June 2020

Accepted 8 June 2020

\section{Keywords:}

Ficus religiosa,

Aspirin,

Pylorus,

Ulcer

Corresponding Author:

E-mail: harikeshvcp@gmail.com

Mob.: +918896778664

DOI: 10.20510/ukjpb/8/i3/1592309444

\begin{abstract}
Ficus religiosa is a medicinal plant and scientifically documented for the pharmacological activities like antidiabetic, anti-inflammatory, antipyretic, etc. The present study was planned to investigate the antiulcer activity of ethanol extract of Ficus religiosa fruit in pylorus ligated and aspirin induced ulceration in experimental animals. The ethanol extract of fruits of Ficus religiosa were prepared by maceration. The antiulcer activity of ethanol extract were evaluated by using pylorus ligated and aspirin induced ulceration models. The administration of ethanol extract of ethanol extract of Ficus religiosa at the dose of 200 $\mathrm{mg} / \mathrm{kg}$ and $400 \mathrm{mg} / \mathrm{kg}$ significantly decreased the ulcer index, $\mathrm{pH}$, gastric volume, free acidity and total acidity compared to control group. The findings proposed the antiulcer activity of ethanol extract of Ficus religiosa fruit.
\end{abstract}

\section{Introduction}

Peptic ulcers are a broad term that includes ulcers of digestive tract in the stomach or the duodenum. It is characterized by the disruption of the mucosal integrity of the esophagus, stomach, or duodenum ${ }^{1}$. The various reports indicates that old age group patients are more susceptible to gastric ulcer. Younger individuals have higher risk of duodenal ulcers ${ }^{2}$. Acute peptic ulcers involve tissues down to the depth of the submucosa. The lesions may be single or multiple, and it develop due to severe illness, shock, burns, severe emotional disturbance, and postsurgical complications. Chronic peptic ulcers penetrate through the epithelial and muscle layers of the stomach wall.

There are several symptoms of ulcer like changes in appetite, nausea, bloody or dark stools, weight loss, indigestion, vomiting and chest pain. Complications of peptic ulcers include haemorrhage, perforation, pyloric stenosis and the development of malignant tumors. Poor digestion and elimination, improper metabolism, mental and physical stress, and difficult to digest food enhance the development of ulcers. Peptic ulcer can be categorized on the basis of location (gastric ulcers are located in the lining of the stomach, duodenal ulcers are located in the duodenal) and on the severity of disease. Numerous other factors are also responsible for progression of peptic ulcers like Tumor Necrosis Factor- $\alpha$ (TNF $\alpha$ ), Reactive Oxygen Species (ROS), release of histamine, incidence of apoptosis and bile acids secretion ${ }^{3}$.

Ulcers are primarily caused by an imbalance between some endogenous aggressive and protective factors in the stomach such as acid-pepsin secretion, integrity of the mucosal barrier, mucus secretion, blood flow, cellular regeneration, prostaglandins, and growth factors ${ }^{4}$. Several factors are also associated in the occurrence of peptic ulcer including stressful lifestyle, alcohol consumption, use of steroidal and non-steroidal anti-inflammatory drugs (NSAIDs; example, aspirin), Helicobacter pylori infections, smoking, lower socio-economic status and family history ${ }^{5}$. Although ulcer is not a deadly disease, it can lead to more serious complications like gastrointestinal bleeding, perforations, penetration of ulcer into adjacent organs and gastric outlet obstruction ${ }^{6}$. 
Medications are used to relieve the pain, heal ulcerations and delay recurrence of ulcerations. These include antibiotics, antacids and proton pump inhibitors ${ }^{7}$. Several drugs are available in the market for gastric ulcer therapy; however, most of these drugs are associated with unwanted side effects ${ }^{8}$. The $75-80 \%$ of the world population still used herbal medicine mainly in developing countries, for primary health care because of better compatibility with the human body, and lesser side effects. Preliminary photochemical screening of this medicinal plant identified in the presence of important secondary metabolites like flavonoids and tannins which are the active principle of anti ulcer activity. Meteria medica provides lots of information about ethno medicinal herbs, which are valuable as antiulcer agents. Various plants like Excoecaria agallocha, Mentha arvensis, Utleria salicifolia, Emblica officinalis, Ficus arnottiana, Alstonia Scholaris, Asparagus racemosus Willd, Azadirachta indica, Bauhinia variegata, Butea frondosa, Carica papaya, Annona squamoza etc. proved active in antiulcer therapy. The use of traditional and modern knowledge can produced better antiulcer drugs with fewer side effects.

Ficus religiosa is an important traditional medicinal plant, belongs to family Moraceae. All the parts of the plants have medicinal properties. Ficus religiosa is affirmed the phytoconstituents of tannins, phenols, flavonoids, alkaloids and steroids, vitamin $\mathrm{K}, \mathrm{n}$ octacosanol, methyl oleanolate, lanosterol, $\beta$-sitosterylDglucoside, stigmasterol, lupen-3-one, amino acids, phenylalanine and isoleucine, carbohydrate, lipid and minerals such as calcium, sodium, potassium, and phosphorus ${ }^{9,10}$. Bark of the plant is used as gonorrhoea, diarrhea, dysentery, cervical cancer, epilepsy, leucorrhea, menorrhagia,vaginal and other urogential disorders haemorrhoids, ulcers, skin diseases and gastrohelcosis. It is also useful in inflammation, anti-anxiety, burning sensation, anti-bactrial, analgesic, anti-diabetic and antioxidant $^{11-13}$. Hence it was planned to evaluate the antiulcer activity of ethanol extract of Ficus religiosa fruit in pylorus ligated and aspirin induced ulceration in experimental animals.

\section{Materials and Methods}

\subsection{Collection and authentication of plant material}

The fruits of Ficus religiosa was collected from R. K. Pharmacy College, Kashipur, Surai Sathiaon, Azamgarh, Uttar Pradesh. The plant was authenticated by Prof. Nawal Kishore Dubey, Department of Botany, Banaras Hindu University Varanasi, India, and voncher specimen no-Morace 2018/1 was deposited in the herbarium of BHU Varanasi for future reference.

\subsection{Preparation of extract}

The dried fruits powdered were macerated with ethanol for 7 days. The menstrum was filtered and again macerated the exhausted powder with ethanol for four days and again repeated for third times. The menstrum obtained from 1, 2 and 3 extraction were combined and concentrated using rotary evaporator at 50
${ }^{\circ} \mathrm{C}$. The dried ethanol extract was kept in refrigerator for further use.

\subsection{Pylorus ligation induced ulcer}

The swiss albino rats were divided into different groups and each group have six animals:

Group I received normal saline

Group II received only aspirin $(200 \mathrm{mg} / \mathrm{kg})$

Group III received ethanol extract $(200 \mathrm{mg} / \mathrm{kg})$

Group IV received ethanol extract $(400 \mathrm{mg} / \mathrm{kg})$

Group V received ranitidine $(50 \mathrm{mg} / \mathrm{kg})$

The animals of groups III to $\mathrm{V}$ received aspirin at a dose of 200 $\mathrm{mg} / \mathrm{kg}$ after $2 \mathrm{hr}$ pretreatment of the extract and standard drug. The animals were anaesthesized with pentobarbitone $35 \mathrm{mg} / \mathrm{kg}$ on 8 day after fasting of $18 \mathrm{hr}$. Abdomen was opened by a midline incision and ligature was placed at the pyrolic and of the stomach taking care not to exclude a blood vessels. At the end of $4 \mathrm{~h}$ after ligation, the rats were sacrificed with excess of anaesthetic ether and the stomach was dissected out. The ulcer index, \%protection, volume of gastric juice, free acidity, and total acidity were determined.

\subsection{Aspirin induced ulcers}

The swiss albino rats were divided into different groups and each group have six animals:

Group I received normal saline and served as normal group Group II received aspirin $200 \mathrm{mg} / \mathrm{kg}$ on the 7 day of experiment Group III received ethanol extract $(200 \mathrm{mg} / \mathrm{kg})$ for 7 days Group IV received ethanol extract $(400 \mathrm{mg} / \mathrm{kg}$ ) for 7 days Group V received ranitidine $(50 \mathrm{mg} / \mathrm{kg})$

On $7^{\text {th }}$ day, Aspirin $(200 \mathrm{mg} / \mathrm{kg})$ was administered to the all animals other than normal group with prior fasting of $24 \mathrm{~h}$. The animals were sacrificed $4 \mathrm{~h}$ after administration of aspirin and the stomach part was excised, cut along the greater curvature, washed carefully with $5.0 \mathrm{~mL}$ of $90 \% \mathrm{NaCl}$ and ulcer areas on the stomach's surface were examined macroscopically and measured on millimetre-square paper. The sum of area $\left(\mathrm{mm}^{2}\right)$ was expressed as $\mathrm{UI}$ and percentage inhibition was calculated ${ }^{14-}$ 16 .

\subsection{Statistical analysis}

The data are expressed as mean \pm standard error mean and statistical comparisons were analysed using the statistical package for social science employing one-way analysis of variance followed by Dunnett's test. The results were considered statistically significant if the $P$ values were less than 0.05 . 


\section{Results and Discussions}

Antiulcer activity of ethanol extract of fruit of Ficus religiosa was evaluated in pylorus ligated and aspirin induced ulceration in experimental animals. In pylorus ligated animals the gastric acid discharge is a significant factor for production of ulceration. At the point when aspirin was directed to pylorus ligated rats it further bothered the acid and the obstruction of the gastric mucosa was diminished consequently forcing wide damage to the glandular area of the stomach. In pylorus ligation model, the animal treated with aspirin significantly increased the ulcer index, $\mathrm{pH}$, gastric volume, free acidity and total acidity compared to normal group. The administration of ethanol extract of Ficus religiosa at the dose of $200 \mathrm{mg} / \mathrm{kg}$ and $400 \mathrm{mg} / \mathrm{kg}$ significantly decreased the ulcer index, $\mathrm{pH}$, gastric volume, free acidity and total acidity compared to control group (Table 1). The ranitidine treated animals also significantly decreased the ulcer index, $\mathrm{pH}$, gastric volume, free acidity and total acidity. The outcomes proposed the antiulcer activity of ethanol extract of Ficus religiosa.

The aspirin induced ulcer animal model shows that the administration of aspirin to the experimental animals of control group significantly increased the ulcer index, $\mathrm{pH}$, gastric volume, free acidity and total acidity compared to normal group. This suggest the ulcer has been induced into the animals. The animals treated with the ethanol extract of Ficus religiosa at the dose of $200 \mathrm{mg} / \mathrm{kg}$ and $400 \mathrm{mg} / \mathrm{kg}$ significantly reduced the ulcer index, $\mathrm{pH}$, gastric volume, free acidity and total acidity compared to control group (Table 2). The ranitidine treated animals also significantly decreased the ulcer index, $\mathrm{pH}$, gastric volume, free acidity and total acidity. The findings outcomes offered the antiulcer activity of ethanol extract of Ficus religiosa.

Table 1: Effect of ethanol extract of Ficus religiosa pretreatment on pylorus ligation-induced gastric ulcer

\begin{tabular}{clccccc}
\hline Group & \multicolumn{1}{c}{ Treatment } & Ulcer index & $\mathbf{p H}$ & Gastric volume & Free acidity & Total acidity \\
\hline I & Normal saline & $3.18 \pm 0.13$ & $3.11 \pm 0.02$ & $1.15 \pm 0.34$ & $34.27 \pm 1.13$ & $43.28 \pm 2.32$ \\
II & Aspirin $(200 \mathrm{mg} / \mathrm{kg})$ & $9.45 \pm 0.32^{\mathrm{a}}$ & $1.26 \pm 0.05^{\mathrm{a}}$ & $3.29 \pm 0.76^{\mathrm{a}}$ & $78.69 \pm 2.05^{\mathrm{a}}$ & $86.52 \pm 1.57^{\mathrm{a}}$ \\
III & $\begin{array}{l}\text { Ethanol extract of Ficus } \\
\text { religiosa }(200 \mathrm{mg} / \mathrm{kg})\end{array}$ & $5.92 \pm 0.11^{*}$ & $4.31 \pm 0.01^{*}$ & $1.24 \pm 0.15^{\star}$ & $40.53 \pm 1.67^{\star}$ & $48.12 \pm 1.34^{*}$ \\
& $\begin{array}{l}\text { Ethanol extract of Ficus } \\
\text { religiosa }(400 \mathrm{mg} / \mathrm{kg})\end{array}$ & $3.46 \pm 0.07^{\star}$ & $5.03 \pm 0.07^{*}$ & $0.67 \pm 0.54^{\star}$ & $34.62 \pm 0.87^{\star}$ & $40.45 \pm 2.13^{\star}$ \\
IV & Ranitidine $(50 \mathrm{mg} / \mathrm{kg})$ & $3.12 \pm 0.08^{*}$ & $5.27 \pm 0.04^{*}$ & $0.51 \pm 0.28^{*}$ & $29.71 \pm 1.43^{*}$ & $38.32 \pm 1.24^{*}$ \\
\hline
\end{tabular}

Value are mean \pm SEM, ${ }^{*} \mathrm{p}<0.05$ represents significant difference from control group, while ${ }^{\mathrm{a}} \mathrm{p}<0.05$ represents significant difference from normal group

Table 2: Effect of ethanol extract of Ficus religiosa in aspirin induced gastric ulcers in rats

\begin{tabular}{|c|c|c|c|c|c|c|}
\hline Group & Treatment & Ulcer index & $\mathrm{pH}$ & Gastric volume & Free acidity & Total acidity \\
\hline 1 & Normal saline & $3.47 \pm 0.49$ & $3.31 \pm 0.07$ & $1.42 \pm 0.51$ & $30.73 \pm 0.76$ & $38.14 \pm 0.17$ \\
\hline II & Aspirin $(200$ mg/kg) & $12.19 \pm 0.26^{\mathrm{a}}$ & $1.05 \pm 0.02^{\mathrm{a}}$ & $6.13 \pm 0.32^{\mathrm{a}}$ & $70.53 \pm 0.54^{\mathrm{a}}$ & $81.37 \pm 0.48^{\mathrm{a}}$ \\
\hline III & $\begin{array}{l}\text { Ethanol extract of Ficus } \\
\text { religiosa }(200 \mathrm{mg} / \mathrm{kg})\end{array}$ & $4.79 \pm 0.63^{*}$ & $3.49 \pm 0.06^{*}$ & $1.84 \pm 0.58^{*}$ & $37.58 \pm 0.16^{*}$ & $43.18 \pm 0.28^{\star}$ \\
\hline IV & $\begin{array}{l}\text { Ethanol extract of Ficus } \\
\text { religiosa }(400 \mathrm{mg} / \mathrm{kg})\end{array}$ & $3.21 \pm 0.13^{*}$ & $4.75 \pm 0.03^{*}$ & $0.91 \pm 0.42^{*}$ & $29.17 \pm 0.83^{*}$ & $37.55 \pm 0.19^{*}$ \\
\hline V & Ranitidine $(50 \mathrm{mg} / \mathrm{kg})$ & $3.04 \pm 0.42^{*}$ & $4.94 \pm 0.01^{*}$ & $0.46 \pm 0.29^{*}$ & $27.42 \pm 0.36^{*}$ & $35.24 \pm 0.23^{*}$ \\
\hline
\end{tabular}

Value are mean \pm SEM, ${ }^{*} \mathrm{p}<0.05$ represents significant difference from control group, while ${ }^{\mathrm{a}} \mathrm{p}<0.05$ represents significant difference from normal group

Aspirin medicine origins a portion subordinate decrease in mucosal prostaglandin $E_{2}$ and prostaglandin $I_{2}$ biosynthesis joined by an expansion in the mean of gastric ulceration. It is along these lines sensible to expect that the perceived gastric mucosal injury instigated by aspirin is because of insufficiency of mucosal prostaglandin ${ }^{17}$. The present study examination uncovers that the ethanol extract of Ficus religiosa at the dose of
$200 \mathrm{mg} / \mathrm{kg}$ and $400 \mathrm{mg} / \mathrm{kg}$ decreased the ulcer index and expanded the gastric $\mathrm{pH}$ of aspirin induced ulcer models.

\section{Conclusion}

The findings of present study suggested the ethanol extract of Ficus religiosa exhibited significant antiulcer activity. Further, cell line study is required for a clear understanding of the mechanism of action.

Pharm \& Biosci J. 2020: 8(3); 13 


\section{Conflict of interest}

None

\section{Author's contributions}

HY, VKM, BY, RY, AKY, AR and RY equally contributed in the experimental work. The manuscript has been checked and approved by all authors before submission to the journal.

\section{References}

1. Kumar A, Dewan B, Rama T. Evaluation of antiulcerogenic properties from the root of Flemingia strobilifera. J Basic Clin Pharm. 2011; 2(1).

2. Pahwa R, Neeta, Vipin K, Kohli K, Clinical manifestations, causes and management strategies of Peptic Ulcer Disease, International Journal of pharma sciences and drug research, 2010, 2(2), 99110.

3. Fatemeh N, Ali M A, Soheila A, Masoumeh G, Hamid M, Mohammad K, African Journal of Pharmacy and pharmacology, 2011, 5(2), 155-159.

4. Freitas CS, Baggio $\mathrm{CH}$, Finau J, Anginoni M, Pizzolatti MG, Santos ARS, Marquez MCA. Inhibition of $\mathrm{H}_{+} / \mathrm{K}+$ ATPase in the gastroprotective effect of Baccharis illinita DC. J Pharm Pharmacol. 2008;60:1105-10.

5. Mota KSdL, Dias GEN, Pinto MEF, Luiz-Ferreira A, Souza-Brito ARM, Hiruma-Lima CA, Barbosa-Filho JM, Batista LM. Flavonoids with Gastroprotective Activity. Molecules. 2009;14:979-1012.

6. Everheart JE. Digestive Diseases in the United States. United States of America: Diane Publishing; 1994. p. 357-408.

7. Tepperman BL, Jacobson ED. Circulatory factors in gastric mucosal defense and repair. In Physiology of the Gastrointestinal Tract, Johnson LR (ed.). Raven Press: New York. 1994.
8. Shirode D, Patel T, Pal Roy S, Jyothi TM, Rajendra SV, Prabhu K, Setty SR. Anti-ulcer properties of $70 \%$ ethanolic extract of leaves of Albizzia lebbeck. Phcog Mag. 2008;4:228-31.

9. Oliver bever B. Oral hypoglycaemic plants in West Africa. J Ethnopharmacol. 1977;2:119-271.

10. Khare CP. Encyclopedia of Indian medicinal plants. Berlin Heidelberg, New York: Springer-Verlag. 2004;50-8.

11. Choudhary GP. Evaluation of ethanolic extract of Ficus religiosa bark on incision and excision wounds in rats. Planta Indica. 2006; 2(3):17-9.

12. Ratnasooriya WD, Jayakody JRAC, Dharmasiri MG. An aqueous extract of trunk bark of Ficus religiosa has anxiolytic activity. Medical Science Research. 1998;26:817-9.

13. Balambal R, Balakrishnan S. International Conference on Traditional Medicine, Madras. Jan. 1986;23-5.

14. Nawale S, Priyanka N, Das S, Raju MG. Data of in vivo screening of antiulcer activity for methanolic extract of Vernonia elaeagnifolia DC. Data in brief. 2019; 23: 113.

15. Balaraman R, Bafana PA. Antiulcer and antioxidant activity of pepticare, a herbomineral formulation, Phytomedicine. 2005; 12: 264-270.

16. Shay $H$, Komarov SA, Fels SS, Meranze D, Gruenstein M, Siplet $\mathrm{H}$. A simple method for uniform production of gastric ulceration in the rat, Gastroenterol. 5 (1945) $43 \mathrm{e} 61$.

17. Sathish R, Sahu A, Natarajan K. Antiulcer and antioxidant activity of ethanolic extract of Passiflora foetida L. Indian J Pharmacol. 2011; 43(3): 336-339. 